504. 001: 504. 064

\title{
- етровськ
}

ьвівський н ціон льний університет імені в н

вул. . орошенк, 41, м. ввів, 79000, кр їн

ро н лізов но суч сний медико-демогр фічний ст н ворівського р-ну ьвівської обл., с ме: дин міку змін природного руху н селення, структуру причин смертності й види 3 хворюв нь н селення. ведено пропозиції щодо його оптиміз ції.

лючові слов : кількість н селення, н роджув ність, смертність, природний приріст, здоров'я, $з$ хворюв ння.

доров'я н селення може формув тися під впливом як внутрішніх (сп дкових, вл стивих окремому індивіду), т к і зовнішніх п р метрів довкілля, його екологічного ст ну, розвитку геоморфологічних процесів тощо, т кож соці льних - умов життя н селення, розвитку соці льної т ре біліт ційної сфери т ін.

дорове екологічне середовище передусім сприяє збереженню здоров'я н селення і попередженню його з хворюв нь, з безпечує норм льні умови пр ці, побуту, відпочинку тощо. ому здоров'я н селення може слугув ти критерієм якості довкілля т н пруження геоекологічної ситу ції.

ермін “людськ екологія” з'явився 1921 р. ого з стосув ли мерик нські вчені орджес і рк. 1927 р. про необхідність дослідження зв'язків між ст ном здоров’я людини і довкіллям з зн ч в . ензил. ізніше (1943-1947) у р нції вийшл книг

. ерре “ риси екології людини”. лежність здоров’я від довкілля підтверджен в 6 г тотомній пр ці ж. ея “ кологія хвороб людини” (1988) [6].

ьогодні відомо б г то спроб оцінити просторову зумовленість суспільного здоров'я т окремих хвороб. н чн кількість пр ць присвячен пошуку інтегр льних пок зників здоров'я н селення з г лом, розробці оптим льних методичних прийомів його оцінки. гомий внесок у цьому н прямі зробили . вцин, . р новський, . удико, . ершинський, . оронов, . гн тьєв, . уцуляк, . ценко, . еллер, . ов льський, . бл пенко, · щенко, - опов, · рохоров, · йх, . яшенко, . евченко, . евчук, . ошин т ін.

плив н орг нізм людини шкідливих чинників довкілля, особливо в промислових регіон х ьвівської обл., з грожує виникненням п тологічних зрушень у ст ні здоров'я н селення. огляду н це проведено дет льні дослідження кризових з медико-геогр фічного погляду регіонів, результ ти яких опубліков но у $[2,5,7,9]$.

ведені тут д ні з свідчують гостроту медико-геогр фічних, с ніт рно-гігієнічних, с ніт рно-епідеміологічних проблем т необхідність доскон лішого їхнього моніторингу і цілеспрямов ного вирішення.

(C) етровськ ., 2010 
е кція орг нізму н вплив спектр природно-господ рських чинників дуже скл дн , тому вр хув ння всіх змін довкілля н був є особливо в жливого зн чення під ч с вивчення ст ну здоров'я н селення т с ніт рно-епідеміологічної ситу ції. ирішити це 3 вд ння можн 3 допомогою підходу, з якого людину т іï здоров'я ст влять у центр системи природ -господ рство і пров дять їі моніторинг. ит ння впливу екологічних проблем н кількість н селення, зниження природного приросту, погіршення вікової структури, поширення хвороб і збільшення спектр з хворюв нь н йгострішим $€$ у меж х густоз селених, промислово розвинутих регіонів, до яких н лежить і ворівщин . ому виникл потреб оцінити вплив чинників довкілля н здоров'я н селення ворівського р-ну ьвівської обл.

ксперти сесвітньої орг ніз ції охорони здоров'я виявили, що ст н здоров'я н 50-52 \% з лежить від способу життя, н 20-22 \% - від сп дковості, н 18-20\%- від ст ну довкілля і н 10-12 \% - від системи охорони здоров'я.

імічне, $\mathrm{p}$ діо ктивне т б ктеріологічне з бруднення повітря, води, грунту, продуктів х рчув ння, т кож шум, вібр ція, електром гнітні поля, іонізуючі випромінюв ння тощо спричинюють в орг нізм х людей в жкі п тологічні явищ, глибокі генетичні зміни (див. т блицю).

к відомо, у середньому 45 \% токсичних речовин потр пляє в орг нізм людини 3 продукт ми х рчув ння, $30 \%$ - 3 питною водою, решт - через повітря.

бруднення тмосферного повітря ворівського р-ну зумовлене розвитком промислового і сільськогоспод рського виробництв , 3 одного боку, т експлу т цією тр нспортних з собів, - з іншого. д ними [3], 2006 р. ст ціон рними джерел ми з бруднення в тмосферне повітря було викинуто 1,3 тис. т шкідливих речовин. середньому н одного мешк нця прип ло 10,4 кг. ля порівняння, н одного мешк нця ьвівщини в середньому прип д ло 43 кг. розр хунку н $1 \mathrm{kм}^{2}$ площі цими ж джерел ми з бруднення було викинуто в тмосферне повітря 0,8 т шкідливих речовин. о ьвівщині цей пок зник - 5,1 т/км².

еред головних скл дових з бруднень тмосферного повітря є сірчистий нгідрид.

p зі н дходження в тмосферу він окиснюється до сульф ту, який з тримується в повітрі протягом трьох-п’яти діб і може переміщ тися н відст нь 1 000-3 000 км від джерел викиду. ор з більше нтропогенне з бруднення тмосфери оксид ми сірки й зоту т зумовлен цим проблем кислотних дощів є однією 3 в жливих екологічних проблем. дих ння людьми повітря, з брудненого кислотним тум ном, спричинює 3 хворюв ння дих льних шляхів тощо.

им ло шкідливих речовин потр пляе в тмосферу від втомобільного тр нспорту.

2006 р. обсяг викидів ст новив 2692 т. них 2096 т оксиду вуглецю, 323 т вуглеводнів, 226 т оксидів зоту, 25 т с жі і 22 т сірчистого нгідриду.

од ткового н пруження до екологічної ситу ції дод є щор з більший потік втотр нспорту, що зумовлено розширенням прикордонних переходів т ктивіз цією міжн родних конт ктів, який ст в “тіньовим” джерелом з бруднення тмосфери.

йон 6 г тий н підземні гідроресурси. е до поч тку ст. у верхньонеогенових відкл д х з хідного схилу озточчя н джерел х річок кло т ерещиця споруджені перші львівські водоз бори прісних підземних вод. ьогодні н йбільшими водоз бор ми прісних підземних вод є оброст нський т льчицький - джерел водопост ч ння обл сного центру; водоз бори р йонного зн чення - шклівський ( $\mathrm{p}$ шк ), новояворівський т яворівський. 
плив п р метрів довкілля н здоров’я людини $[4,8,11,13]$

\begin{tabular}{|c|c|c|}
\hline нгредієнт & $\begin{array}{c}\text { жерело } \\
\text { н дходження }\end{array}$ & слідки впливу \\
\hline ил & $\begin{array}{l}\text { тмосферне } \\
\text { повітря }\end{array}$ & $\begin{array}{l}\text { ронхіт, бронхі льн стм , пневмонія, з хворюв ння } \\
\text { серцево-судинної системи, інфекційні з хворюв ння, } \\
\text { злоякісні новоутворення }\end{array}$ \\
\hline кис вуглецю & $\begin{array}{l}\text { тмосферне } \\
\text { повітря }\end{array}$ & иснев недост тність, безпліддя \\
\hline $\begin{array}{l}\text { ірчистий } \\
\text { нгідрид }\end{array}$ & $\begin{array}{l}\text { тмосферне } \\
\text { повітря }\end{array}$ & ронхіт, пошкодження печінки і кровоносної системи \\
\hline $\begin{array}{l}\text { полуки сірки й } \\
\text { зоту }\end{array}$ & $\begin{array}{l}\text { тмосферне } \\
\text { повітря }\end{array}$ & $\begin{array}{l}\text { мфізем (звуження дих льних шляхів), порушення ві- } \\
\text { т мінного обміну }\end{array}$ \\
\hline винець & $\begin{array}{l}\text { тмосферне } \\
\text { повітря, вод , } \\
\text { грунт }\end{array}$ & $\begin{array}{l}\text { ункціон льні зміни центр льної нервової системи, пе- } \\
\text { чінки, нирок, мозку, ст тевих орг нів }\end{array}$ \\
\hline отооксид нТи & $\begin{array}{l}\text { тмосферне } \\
\text { повітря }\end{array}$ & $\begin{array}{l}\text { ідст в ння у м сі, зниження ктивності ферментів у } \\
\text { крові, зменшення віт мінного б л нсу, п тологічні змі- } \\
\text { ни у внутрішніх орг н х і центр льній нервовій системі }\end{array}$ \\
\hline $\begin{array}{r}\text { длишок } \\
\text { хлоридів i } \\
\text { сульф тів }\end{array}$ & од , грунт & орушення функцій системи тр влення \\
\hline $\begin{array}{l}\text { длишок } \\
\text { к льцію }\end{array}$ & од , грунт & мені у нирк х і сечовому міхурі \\
\hline $\begin{array}{l}\text { длишок } \\
\text { нітр тів }\end{array}$ & од , грунт & $\begin{array}{l}\text { вороби дих льної т серцево-судинної систем, метге- } \\
\text { моглобінемія, зменшення вмісту віт мінів в орг нізмі, } \\
\text { зниження стійкості орг нізму до онкогенних чинників }\end{array}$ \\
\hline $\begin{array}{l}\text { Нижений вміст } \\
\text { фтору }\end{array}$ & од & рієс зубів \\
\hline $\begin{array}{r}\text { ідвищений } \\
\text { вміст фтору }\end{array}$ & од & $\begin{array}{l}\text { люороз, ур ження зубів } 3 \text { утворенням н них плям } \\
\text { жовто-бурої пігмент ції, дефектів ем лі тощо }\end{array}$ \\
\hline ефіцит йоду & од , грунт & $\begin{array}{l}\text { ндемічний зоб (збільшення розмірів і порушення функ- } \\
\text { ції щитоподібної з лози) }\end{array}$ \\
\hline $\begin{array}{l}\text { длишок } \\
\text { к дмію }\end{array}$ & од , грунт & вороб іт й-іт й, 3 хворюв ння серця \\
\hline длишок хрому & од & Хворюв ння нирок \\
\hline длишок міді & од & немія, геп тит, інтоксик ція \\
\hline длишок ртуті & од & $\begin{array}{l}\text { ункціон льні зміни центр льної нервової системи, } \\
\text { системи орг нів кровообігу, сечовиділення }\end{array}$ \\
\hline длишок цинку & од , грунт & $\begin{array}{l}\text { хворюв ння рухового п р ту, діяльності орг нів } \\
\text { тр влення }\end{array}$ \\
\hline $\begin{array}{l}\text { длишок } \\
\text { рсену }\end{array}$ & од , грунт & $\begin{array}{l}\text { Хворюв ння нирок, печінки, легень, серцево-судин- } \\
\text { ної системи }\end{array}$ \\
\hline $\begin{array}{l}\text { естициди і } \\
\text { мінер льні } \\
\text { добрив }\end{array}$ & од , грунт & $\begin{array}{l}\text { труєння, туберкульоз, шлунково-кишкові, серцево-су- } \\
\text { динні з хворюв ння, посл блення імунної системи, роз- } \\
\text { виток злоякісних новоутворень, ном лії новон родже- } \\
\text { них, зниження трив лості життя }\end{array}$ \\
\hline
\end{tabular}

н слідок розробки сірч них руд н ворівському родовищі сірки у воді водоносного горизонту флювіогляці льних відкл дів підвищил ся кількість стронцію, через що мінер ліз ція води в р. кло зросл до 1,6 г/дм ${ }^{3}$ (норм $-0,25$ г/дм $\left.{ }^{3}\right)$, і вод 3 гідрок рбон тно-к льцієвої ст л сульф тно-к льцієвою із вмістом стронцію 11,5 мг/дм³. 
одній з криниць н лівобережжі p. кло (с. оруденко) мінер ліз ція досягл 1,3 г/дм ${ }^{3}$ (р ніше стронцію у водоносному горизонті не було). ожливе відновлення сульф тів до сірководню. міст нітр тів у воді криниць колив ється від 25 до 170 мг/дм ${ }^{3}$ [10].

г льною особливістю водоз борів ворівського р-ну є н дзвич йно м л кількість фтору в питній воді. од, яку використовують для з безпечення деяких н селених пунктів, зовсім не містить фтору, що може слугув ти однією з головних причин ур ження зубів у дітей т дорослих к рієсом. е певною мірою 3 свідчують результ ти клінічних досліджень.

ериторія р йону з йнят господ рсько-побутовими відход ми т відход ми гірничодобувної промисловості. Г лом твердими побутовими відход ми вкрито 25,72 г , площ відпр цьов них земель ст новить 3512 г (ст ном н 2006 р.). території p йону н лічується 27 діючих сміттєзв лищ, пр ктично нем п спортизов них сміттєзв лищ. в з них (сміттезв лищ овояворівської міської т в но- $р$ нківської сільської р д) не відповід ють с ніт рно-екологічним вимог м. ля виготовлення проектно-кошторисної документ ції для сміттєзв лищ в но- $\mathrm{p}$ нківської сільської р ди нем коштів. огляду н ліквід цію к р'єру, де розміщене сміттєзв лище м. овояворівськ , необхідний вибір нової земельної ділянки.

дну з основних функцій у ст біліз ції екологічного ст ну будь-якої території виконують ліси. цьому р зі простежується тенденція: чим вищ лісистість території, тим ліпш іiї екологічн ситу ція. ісовий фонд ворівського р-ну ст ном н 01.01.2006 p. ст новив 61532,2 г , бо 39,85 \% площі р йону. н чн ч стк р йону - 7,03\% - це відкриті землі без рослинного покриву бо з незн чним рослинним покривом. к структур лісового фонду з г лом є несприятливою (потребує реконструкції) т нег тивно вплив $є$ н формув ння еколого-геогр фічної ситу ції.

тлі дії нег тивних чинників довкілля н орг нізм людини виник ють т кі з хворюв ння, як серцево-судинні, онкологічні, дистрофічні зміни, лергія, цукровий ді бет, гормон льні дисфункції, порушення у розвитку плоду, пошкодження сп дкового п р ту клітини.

рямими н слідк ми з гострення екологічних проблем є зменшення кількості н селення, н роджув ності, зниження природного приросту, погіршення вікової структури, поширення хвороб і збільшення спектр 3 хворюв нь. ндик тором цих процесів певною мірою може слугув ти дин мік н селення.

т ном н 01.01.2007 р. у ворівському р-ні прожив ло 122,5 тис. осіб. них міського н селення - 55,5, сільського - 67,0 тис. осіб. ротягом 1979-1997 pp. н селення зрост ло (відповідно, 110,0 і 124,6 тис. осіб), протягом 1997-2007 рр. - зменшув лося (відповідно, 124,6 і 122,5 тис. осіб) (рис. 1). иту ція неодн ков серед міського і сільського н селення. окрем, кількість міського н селення зрост є, сільського зменшується. оефіцієнт природного приросту н селення н ворівщині поступово зменшується (з 7,4\%о в 1990 р. до 2,2 \%о у 2006 р.), з 2005 по 2006 рр. простежене незн чне збільшення (н $1 \% 0)$. дн к протягом усього досліджув ного періоду природний приріст є дод тним (рис. 2).

оефіцієнт природного приросту міського н селення хоч незн чно, ле т кож зменшився (з 5,2\%о в 2006 р. до 4,9\%о в 2007 р.). йвищим цей пок зник був 1990 р. 10,9\%о (рис. 3). одо сільського н селення, то з 1990 р. спостережено зменшення природного приросту н селення, $з 2004$ р. він ст в від’ємним (-2,6\%о у 2007 р.) (рис. 4). 


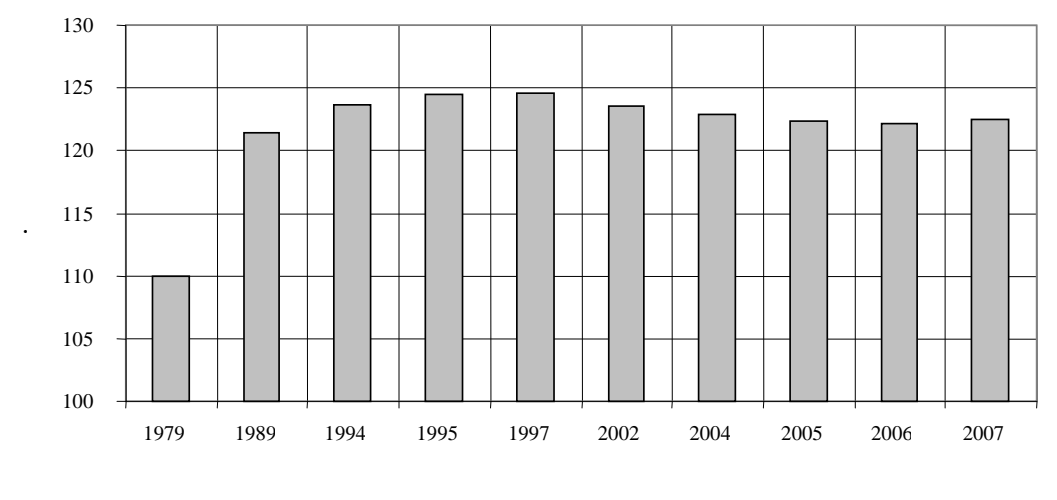

ис. 1. ин мік кількості н селення ворівського р-ну $(3 \quad[3,12])$.

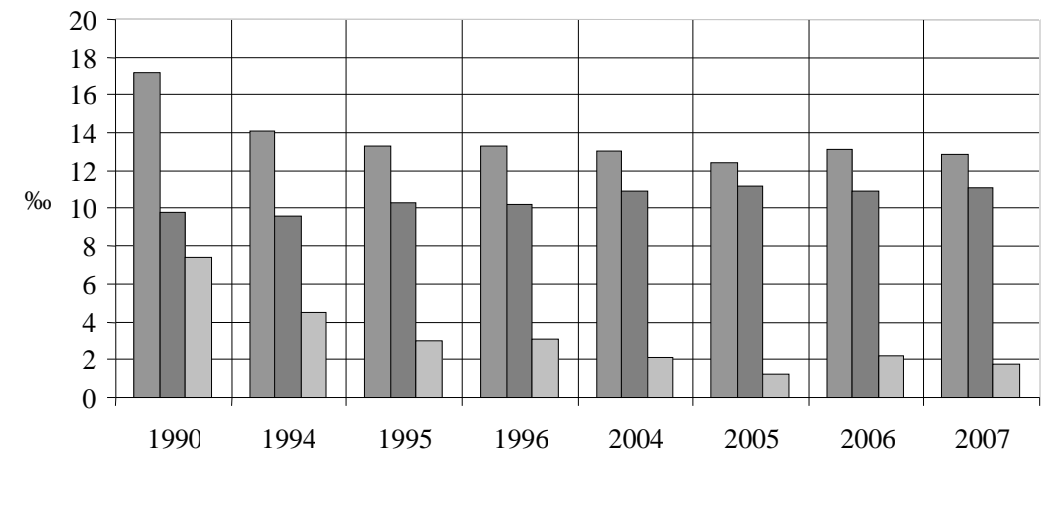

$\square 1 \quad \square 2 \quad \square 3$

ис. 2. ин мік природного руху н селення ворівського р-ну (3 $[3,12]): 1$ - н роджені; 2 - померлі; 3 - природний приріст.

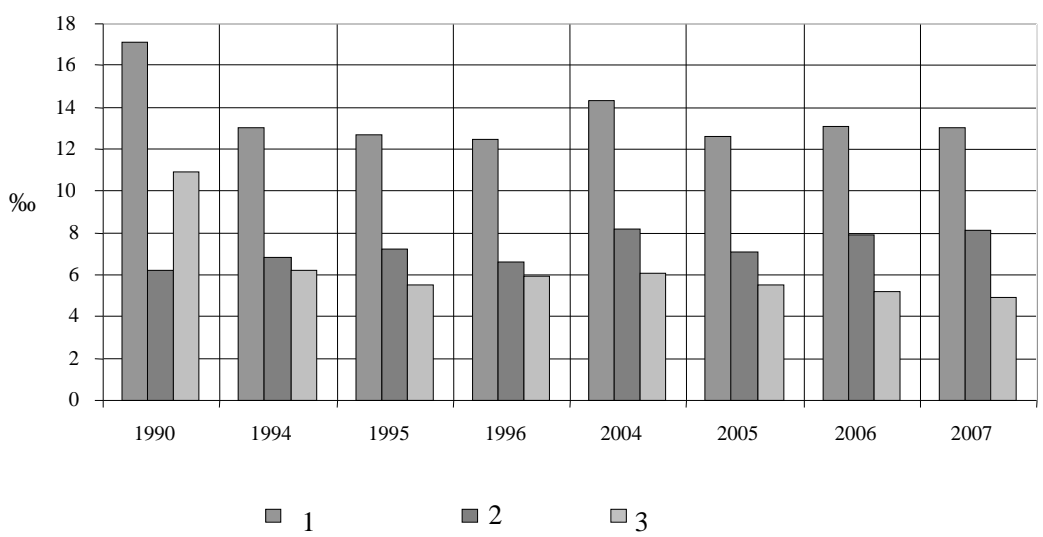

ис. 3. ин мік природного руху міського н селення ворівського р-ну $(3 \quad[3,12])$. озн чення ті ж, що й н рис. 2. 
мертність н селення ворівського р-ну спричинен т кими хвороб ми: інфекційні хвороби, новоутворення, хвороби орг нів кровообігу, дих ння, тр влення, зовнішні причини з хворюв ності тощо. ок зник смертності н селення від цих хвороб 2007 р. ст новив 1116 осіб, що нижче порівняно з 1999 р. йбільше померло від з хворюв нь орг нів кровообігу: 2007 р. - 73,49 \%, 1999 р. - 69,20\%. другому місці - новоутворення, д лі - зовнішні причини з хворюв нь і пр ктично одн кову ч стку ст новлять 3 хворюв ння орг нів дих ння, тр влення т інфекційні (рис. 5).

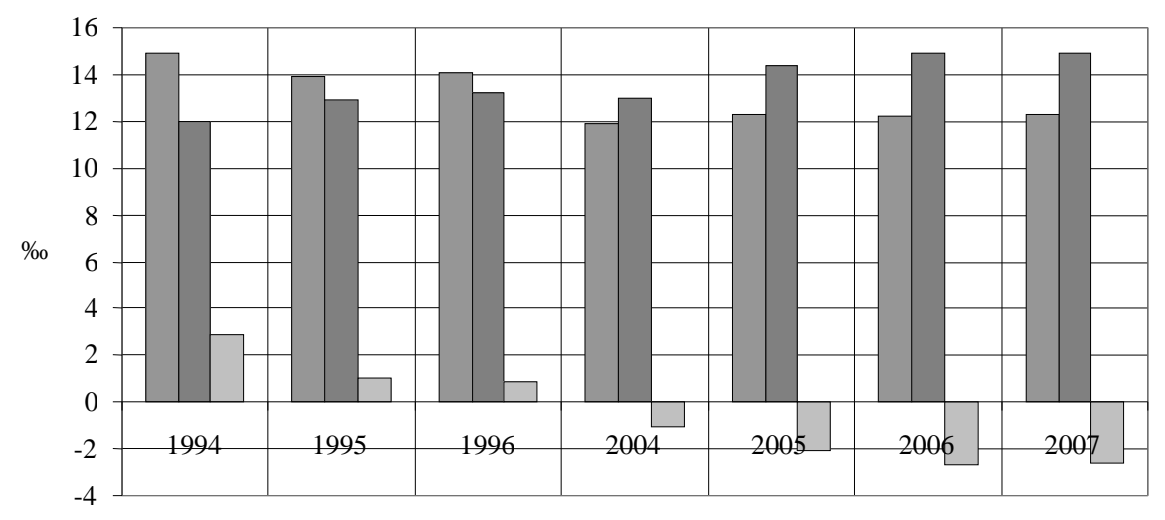

ОКИ

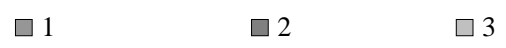

ис. 4. ин мік природного руху сільського н селення ворівського р-ну $(3 \quad[3,12])$. озн чення ті ж, що й н рис. 2.

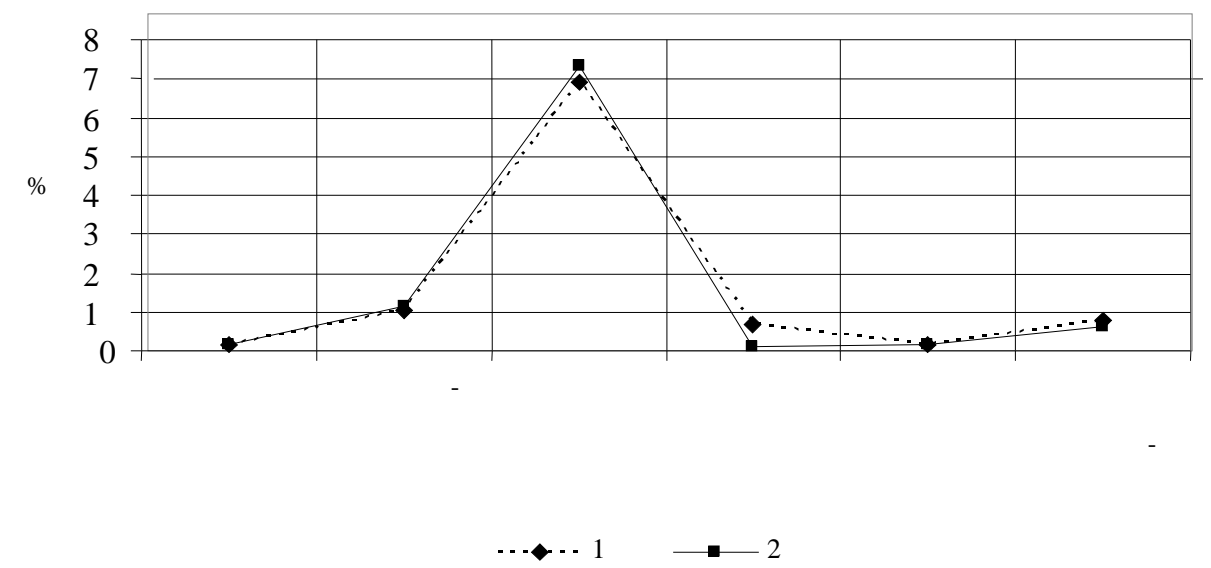

ис. 5. труктур причин смертності н селення яворівського р-ну у 1999 (1) т 2007 рр. (2) 
ок зники поширеності з хворюв нь серед дитячого н селення р йону не м ють стійкої тенденції до зниження т $є$ н рівні попередніх років (рис. 6) [1].

еред 3 хворюв нь н селення ворівського р-ну перше місце посід ють тр вми й отруєння, д лі - хвороби сечост тевої системи і мигд ликів т деноїдів. йменше 3 хворюв нь н хронічний ревм тизм і пневмонію (рис. 7).

структурі інфекційних 3 хворюв нь ст ном н 2006 р. перев ж ють кишкові інфекції т кір (рис. 8).

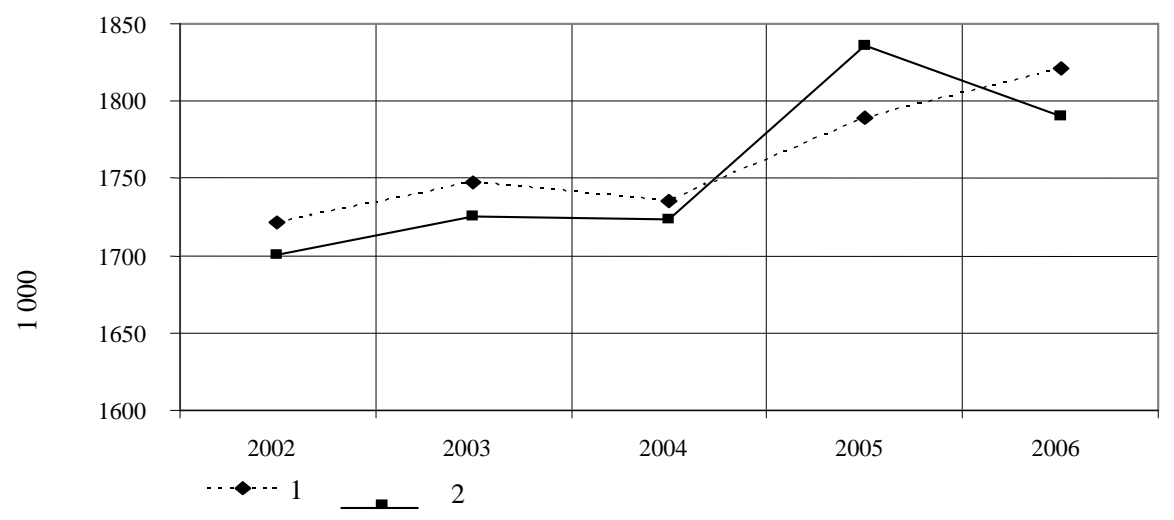

ис. 6. івень поширеності з хворюв нь дитячого н селення ворівського р-ну віком до 14 (1) т від 7 до 14 років (2).

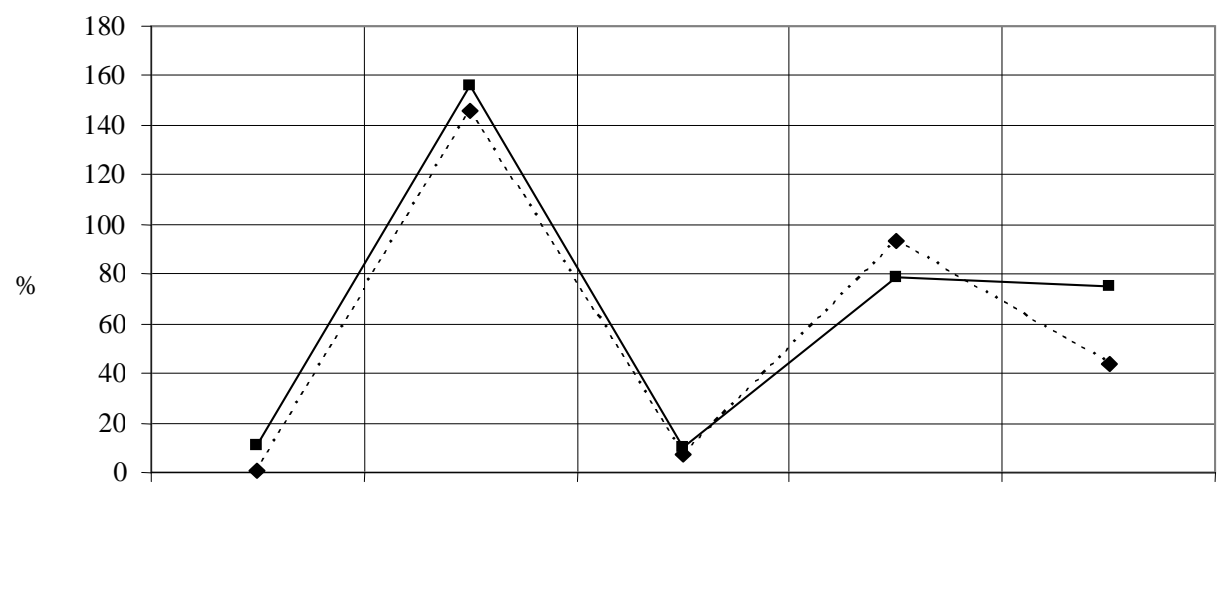

ис. 7. иди з хворюв нь н селення ворівського р-ну в 2004 (1) т 2005 рр. (2). 


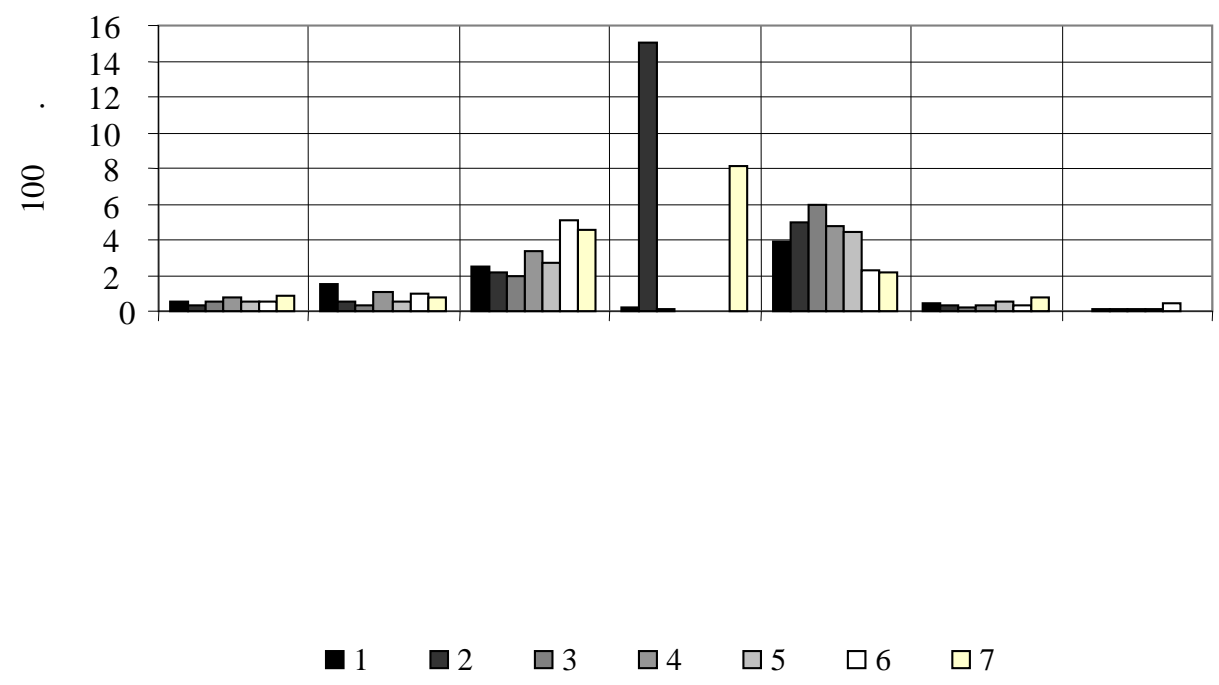

ис. 8. хворюв ність н селення ворівського р-ну (н 100 тис. осіб). оки: 1 - 2000; $2-2001 ; 3-2002 ; 4-2003 ; 5-2004 ; 6-2005 ; 7-2006$.

тже, у високій з хворюв ності н селення ворівського р-ну н спектр хвороб суттєву роль відігр ють природно- нтропогенні чинники. гострення екологічних проблем потребує переорієнт ції схем ведення господ рств н т кі в рі нти, які відповід тимуть екологічним вимог м щодо використ ння природних ресурсів ворівського p-ну, з безпечув тимуть н лежний соці льно-економічний розвиток регіону. дним 3 н прямів подол ння цієї ситу ції вб ч ємо розвиток рекре ційної індустрії.

1. н ліз с ніт рно-епідеміологічної ситу ції у ьвівській обл сті т пок зники діяльності держс непідслужби з 2002-2006 роки. ьвів, 2007. 207 с.

2. ірч $\kappa$. . еребіг з хворюв нь п родонту в підлітків, що прожив ють у регіон х інтенсивного добув ння сірки // ит ння соціоекології. . 2: тері ли ершої всеукр. конф. / ред. . . чинського т ін. ьвів: , 1996. . 167-168.

3. овкілля ьвівщини. т тист. зб. ьвів, 2006. 105 с.

4. ов льчук ., етровськ . еоекологія озточчя. ьвів: ім. . р нк, 2003. 192 с.

5. рупник. ., ібік. ., езвушко . . $m$ ін. оці льно-екологічні спекти к рієсу т нек ріозних ур жень твердих тк нин зубів // ит ння соціоекології. . 2: тері ли ершої всеукр. конф. / ред. . . чинського т ін. ьвів: , 1996. . 165-167.

6. 'ягченко . ., речишкін . . оль соці льної в леології // ит ння соціоекології. . 2: тері ли ершої всеукр. конф. / ред. . . чинського т ін. ьвів: , 1996. . 154-155.

7. $y \partial p$. . плив шкідливих ф кторів довкілля н ст н здоров'я н селення м. икол єв ьвівської обл сті // ит ння соціоекології. . .2: тері ли ершої всеукр. конф. / ред. . . . чинського т ін. ьвів: , 1996. .161-162.

8. икифоров . . винець в л ндш фт х экосистем // ехногенные потоки веществ в л ндш фт х и состояние экосистем. . . $\quad$ ук , 1981. . 87-91.

9. $\quad$ сююк. ., ишк . ., $\quad$ л хов . . досвіду комплексних соціоекологічних досліджень у вивченні ст ну здоров'я н селення рик рп тського сірконосного р йону // ит ння со- 
ціоекології. . 2: тері ли ершої всеукр. конф./ ред. . . чинського т ін. ьвів: , 1996. . 163-165.

10. едосеев . . омплексн я оценк регион льного влияния техногенных ф кторов н гидрогеологические и геологические условия территории деятельности “ п дукргеология”. тчет. ьвов, 1986.

11. річков . . ктори виникнення екологічних небезпек і їх вплив н ст н довкілля кр їни // тр тегія екологічної безпеки (регіон льний контекст). ьвів, 1999. . 49-57.

12. исельність н селення ьвівської обл сті н 1 січня 2007 року. ьвів, 2007. 42 с.

13. овкун . . т н оточуючого середовищ як критерій ст ну здоров'я н селення // еоморфологія в кр їні: новітні н прямки і з вд ння. ., 1999. . 140-143.

\section{EVALUATION OF THE RECENT MEDICAL-DEMOGRAPHICAL STATE OF YAVORIV DISTRICT IN LVIV REGION}

\section{Petrovska}

Ivan Franko National University of Lviv, . Doroshenko St., 41, UA - 79000 Lviv, Ukraine

The actual medical-demographical state of Yavoriv district in Lviv region has been analyzed. Namely the dynamics of natality, structure of death causes and types of illness of inhabitants were analyzed. Based on the obtained results the proposals for situation improvement are worked out.

Key words: population, natality, death causes, nature increase of population, health, illness.

C

ро н лизиров но современное медико-демогр фическое состояние воровского р-н ьвовской обл., именно: дин мику изменений природного движения н селения, структуру причин смертности и виды з болев ний н селения. но предложения относительно его оптимиз ции.

лючевые слов : численность н селения, рожд емость, смертность, природный прирост, здоровье, з болев ние.

т ття н дійшл до редколегії 03.05.2009

рийнят до друку 20.09.2009 